REPORTS OF MORPHOLOGY
$\begin{gathered}\text { Official Journal of the Scientific Society of Anatomists, } \\ \text { Histologists, Embryologists and Topographic Anatomists } \\ \text { of Ukraine } \\ \text { journal homepage: https://morphology-journal.com }\end{gathered}$

\title{
Features of skinfold thickness in men with benign nevi
}

\section{Nabil Basim Yousif Haddad}

National Pirogov Memorial Medical University, Vinnytsya, Ukraine

\section{ARTICLE INFO}

Received: 14 September 2021

Accepted: 12 October 2021

UDC: $616.5-003.829-037-084-07$

\section{CORRESPONDING AUTHOR}

e-mail: nabil.basim@gmail.com Nabil Basim Yousif Haddad

\section{CONFLICT OF INTEREST}

The authors have no conflicts of interest to declare.

\section{FUNDING}

Not applicable.
Nevi, although benign neoplasms of the skin, but have a certain tendency to malignancy, which is influenced by various external and internal human factors. Predicting the risk of benign nevi against this background is an important topic for experimental research. The aim of the study was to establish the features of the skinfold thickness (SFT) in men of the first adult age with benign nevi. SFT was determined according to the Bunak scheme for men (aged 22-35 years) with melanocyte benign simple nevi $(n=34)$, melanocyte benign dysplastic nevi $(n=27)$, melanocyte benign congenital nevi $(n=14)$ and non-melanocyte benign ( $n=17)$. The control group - SFT of 82 practically healthy men of the same age group was selected from the data bank of the Research Center of National Pirogov Memorial Medical University, Vinnytsya. Statistical processing of the results was performed in the license package "Statistica 5.5" using non-parametric evaluation methods. It was found that in practically healthy men higher than in patients SFT on the anterior and posterior surfaces of the shoulder and thigh (in all groups of patients); SFT on the forearm, at the lower angle of the scapula, chest and shin (only in patients with melanocyte benign dysplastic nevi). Also in healthy men are found lower than in patients - SFT on the side (in all groups of patients); SFT in the abdomen (in patients with melanocyte benign simple and non-melanocyte benign nevi). When comparing SFT between patients with benign nevi, in most cases, lower values of SFT found in patients with melanocyte benign dysplastic nevi. The obtained results indicate the initial manifestations of abdominal (android) type of fat deposition in the body in patients with benign nevi (most pronounced in patients with melanocyte benign simple nevi).

Keywords: benign nevi, skinfold thickness, men.

\section{Introduction}

Nevi are usually benign melanocyte neoplasms that occur either in utero or during life and have different types of localization - both on the skin and on the mucous membranes of the mouth, genitals, etc. [10, 11, 12]. Nevi include common nevi, Spitz's nevus, blue nevus, and cutaneous melanocytosis; they can all be both congenital and acquired. According to the latest classifications, melanocytomas, which have a higher risk of malignancy, ie a transitional state between benign and malignant skin neoplasms, are considered a separate type of nevus [7, 21].

When it comes to malignancy of nevi, the worst result of this process is degeneration into melanoma, the prevalence of which is steadily increasing, as is the severity of the consequences it causes. From 2000 to 2006, the YPLL rate due to melanoma mortality increased by $8.7 \%$, and the cost of treatment was more than $\$ 400,000$ [9]. That is why medicine is currently moving towards creating new methods for early diagnosis of skin cancer [20].

The prevalence of nevi is heterogeneous and varies in different countries and regions [16]. In Grenada (Spain), a survey of children aged 8-10 years revealed that the average number of nevi was 19.38 units (mostly less than $2 \mathrm{~mm}$ in diameter) [3]. In Olmsted County (USA) from 2000 to 2005, the overall incidence of nevi was 76.0 per 100,000 personyears [1].

If we consider the internal factors, then for most types of nevi, the characteristic areas of mutations responsible for their occurrence have been identified. Thus, for congenital normal nevi it is a mutation of BRAF V600E, for blue nevus GNAQ, for acquired Spitz nevus it is HRAS [21].

Of the external factors, most attention is paid to insolation $[11,16,21]$. But the theory of the impact of smoking on increasing the risk of nevi has not found practical confirmation in experimental studies [18]

Spanish scientists conducted a study taking into account the constitutional elements - the phototype of man in order to identify the predisposition to nevi. According to the results of the study, the occurrence of nevi is associated with a low 
type of phototype (ie the presence of blonde hair and fair skin) [3]. Thus, it can be assumed that a constitutional approach can be promising for assessing the risk of nevi.

The aim of the study was to establish the features of skinfold thickness in men of the first adult age with benign nevi.

\section{Materials and methods}

Men aged 22 to 35 years with benign nevi (34 with melanocyte benign simple nevi, 27 with melanocyte benign dysplastic nevi, 14 with melanocyte benign congenital nevi and 17 with non-melanocyte benign nevi), laboratory tests and histopathological examinations were performed on the base of Military Medical Clinical Center of the Central Region and the Department of Dermatology and Venereal Diseases with a course of postgraduate education National Pirogov Memorial Medical University, Vinnytsya.

Committee on Bioethics of National Pirogov Memorial Medical University, Vinnytsya (protocol № 10 From 26.11. 2020) found that the studies do not contradict the basic bioethical standards of the Declaration of Helsinki, the Council of Europe Convention on Human Rights and Biomedicine (1977), the relevant WHO regulations and laws of Ukraine.

The diagnosis of nevi was established according to a two-stage algorithm for the classification of pigmented tumors, which was adopted at the First World Congress of Dermatoscopy (Rome, 2001) [17].

All patients were determined skinfold thickness (SFT) according to the scheme of V.V. Bunak [4].

As a control from the database of the research center of the National Pirogov Memorial Medical University, Vinnytsya were selected SFT indicators of 82 healthy men of the same age group.

Statistical processing of the results was performed in the license package "Statistica 5.5" using non-parametric evaluation methods. The reliability of the difference between the values between the independent quantitative values was determined using the U-Mann-Whitney test.

\section{Results}

It was found that SFT on the posterior surface of the shoulder in healthy men was significantly $(p<0.001)$ higher than in men with benign nevi; and in men with melanocyte benign congenital nevi - significantly greater $(p<0.05)$ than in patients with melanocyte benign dysplastic nevi (Fig. 1).

SFT on the anterior surface of the shoulder in healthy men is significantly $(p<0.01-0.001)$ higher than in men with benign nevi (Fig. 2).

SFT on the forearm in healthy men was significantly $(p<0.001)$ higher than in men with melanocyte benign dysplastic nevi; and in men with melanocyte benign dysplastic nevi - significantly less $(p<0.05)$ than in patients with melanocyte benign simple nevi and tends to lower values $(p=0.065)$ than in patients with non-melanocyte benign nevi (Fig. 3).

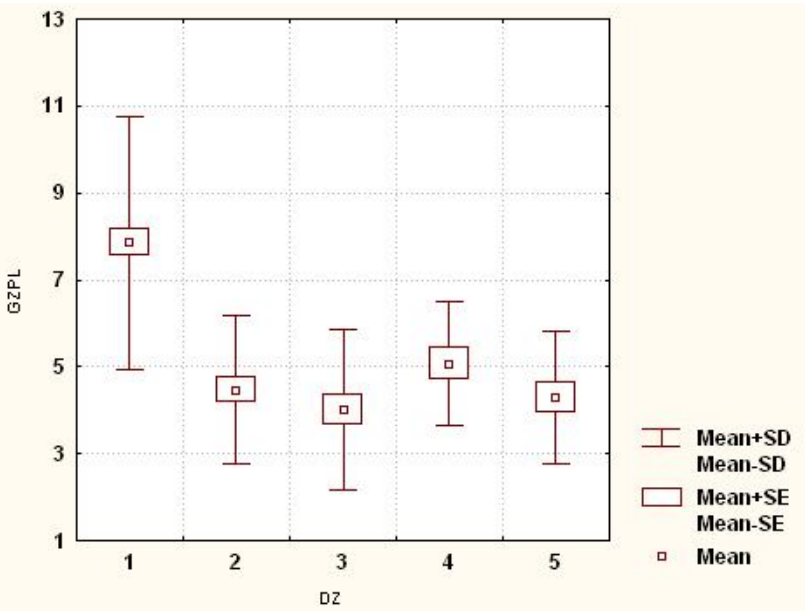

Fig. 1. Posterior shoulder SFT (GZPL) in healthy and sick men with benign nevi $(\mathrm{mm})$. In this and the following figures: $D Z$ - the corresponding groups of men; 1 - healthy men; 2 - men with melanocyte benign simple nevi; 3 - men with melanocyte benign dysplastic nevi; 4 - men with melanocyte benign congenital nevi; 5 - men with nonmelanocyte benign nevi; Mean - average value; Mean \pm SE - average value \pm mean error; Mean $\pm S D$ - mean \pm standard deviation.

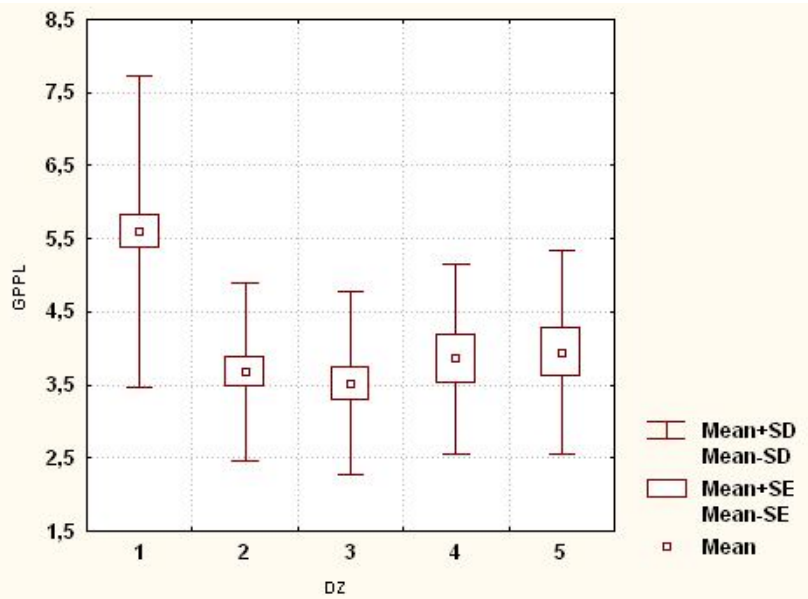

Fig. 2. Anterior shoulder SFT (GPPL) in healthy and sick men with benign nevi $(\mathrm{mm})$.

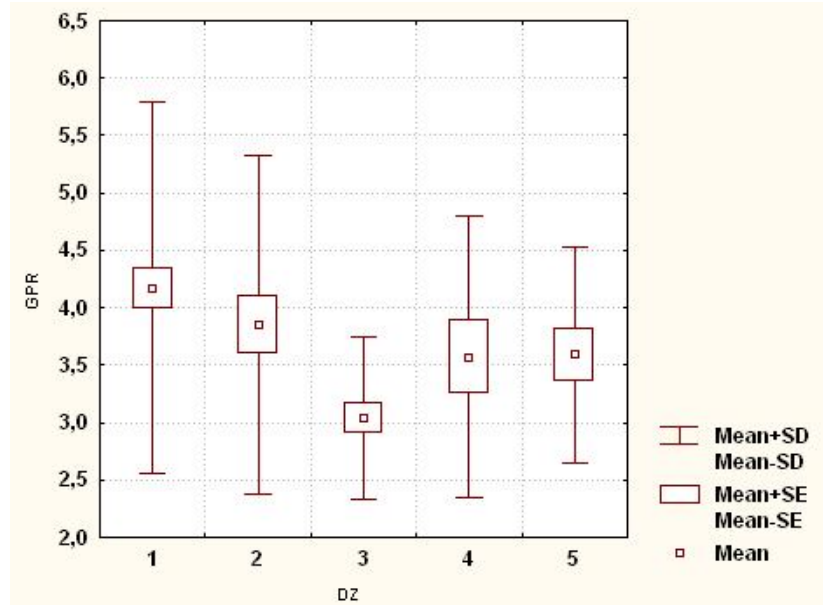

Fig. 3. SFT on the forearm (GPR) in healthy and sick men with benign nevi $(\mathrm{mm})$. 


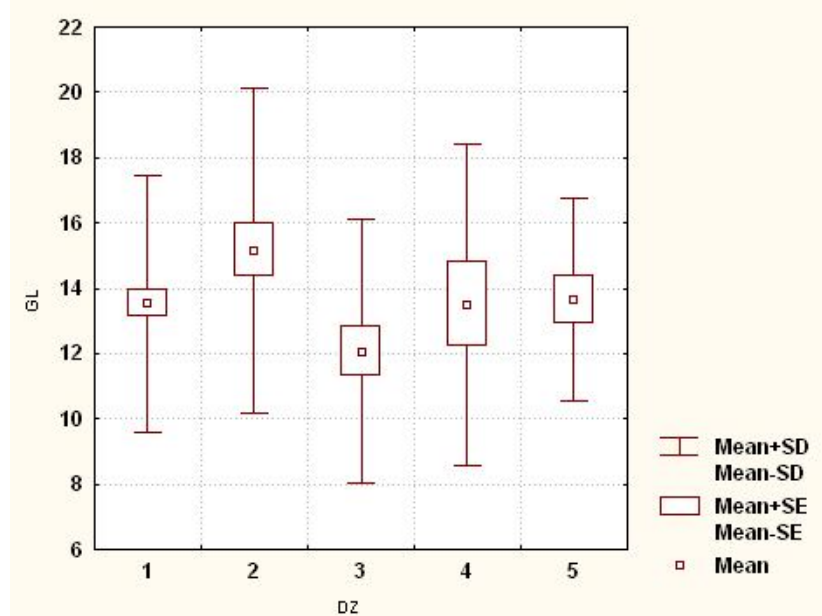

Fig. 4. SFT under lower angle of the scapula (GL) in healthy and sick men with benign nevi $(\mathrm{mm})$.

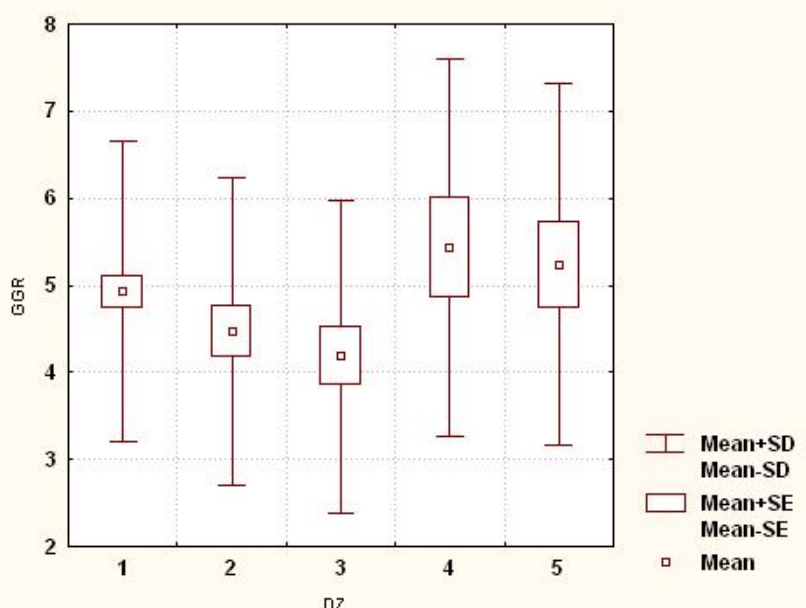

Fig. 5. SFT on the chest (GGR) in healthy and sick men with benign nevi $(\mathrm{mm})$.

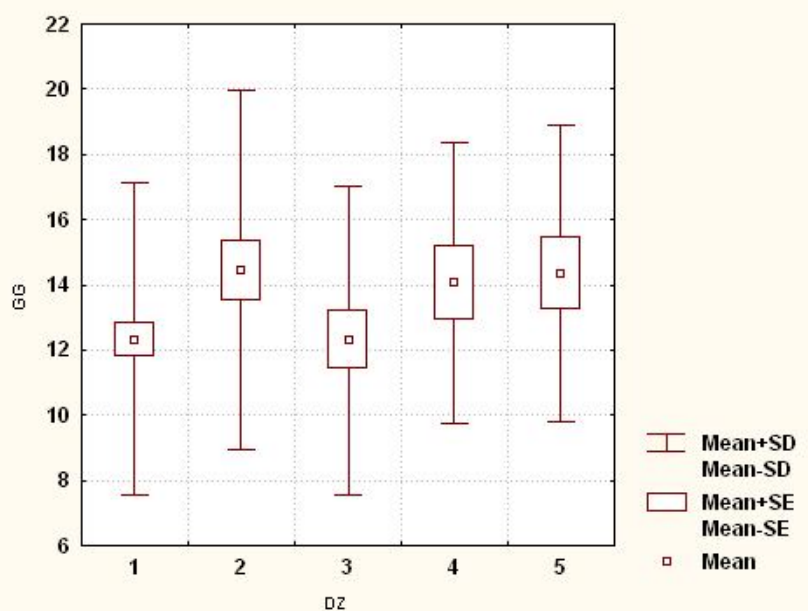

Fig. 6. Abdominal SFT (GG) in healthy and sick men with benign nevi $(\mathrm{mm})$.

SFT under lower angle of the scapula in healthy men is significantly $(p<0.05)$ higher than in men with melanocyte benign dysplastic nevi; and in men with melanocyte benign dysplastic nevi - significantly less $(p<0.01)$ than in patients with melanocyte benign simple nevi and has a slight tendency to lower values $(p=0.085)$ than in patients with non-melanocyte benign nevi (Fig. 4).

SFT on the breast in healthy men is significantly $(p<0.05)$ higher than in men with melanocyte benign dysplastic nevi; and in men with melanocyte benign dysplastic nevi - tends to lower values $(p=0.054$ and $p=0.075)$ than in patients with melanocyte benign congenital and non-melanocyte benign nevi (Fig. 5).

Abdominal SFT in healthy men is significantly $(p<0.05)$ lower or has a slight tendency to lower values $(p=0.086)$ than in patients with melanocyte benign simple and nonmelanocyte benign nevi (Fig. 6).

SFT on the side in healthy men is significantly $(p<0.01-$ $0.001)$ lower than in men with benign nevi; and in men with melanocyte benign simple nevi - significantly $(p<0.05)$ greater or tends to higher values $(p=0.066)$ than in patients with melanocyte benign dysplastic and non-melanocyte

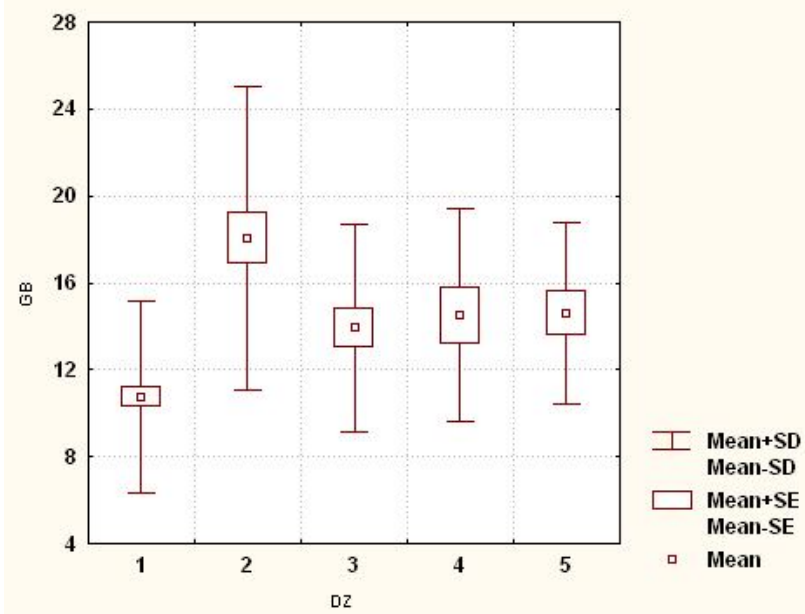

Fig. 7. SFT on the side (GB) in healthy and sick men with benign nevi $(\mathrm{mm})$.

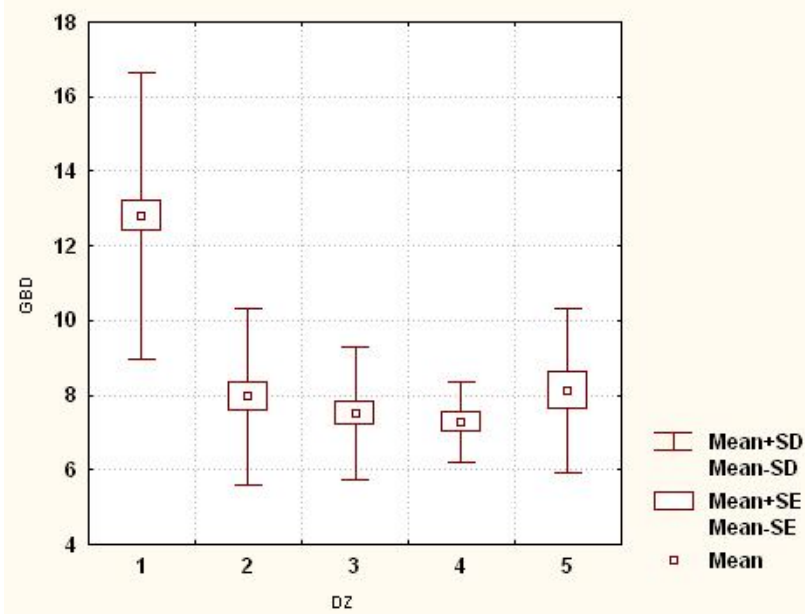

Fig. 8. SFT on the thigh (GBD) in healthy and sick men with benign nevi $(\mathrm{mm})$. 


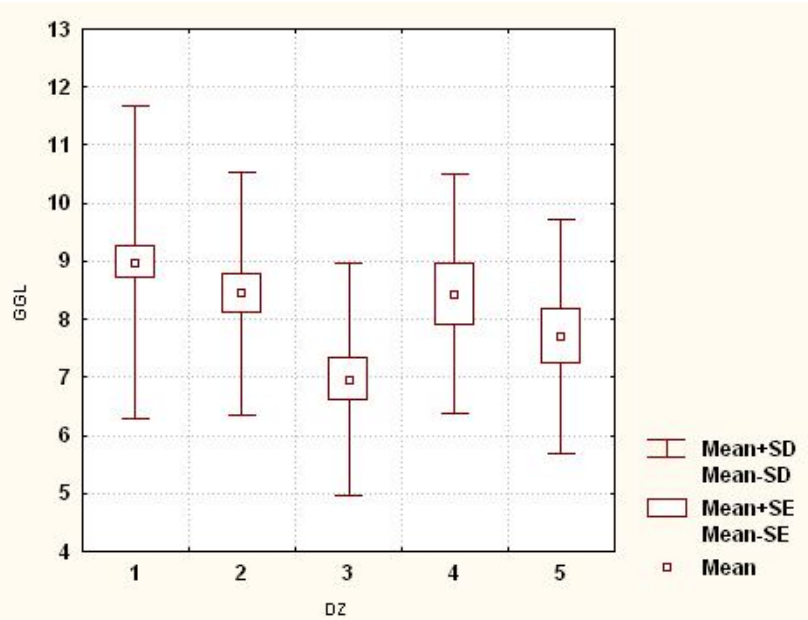

Fig. 9. SFT on the shin (GGL) in healthy and sick men with benign nevi $(\mathrm{mm})$.

benign nevi (Fig. 7).

SFT on the thigh in healthy men is significantly $(p<0.001)$ higher than in men with benign nevi; and in men with nonmelanocyte benign nevi - tends to higher values $(p=0.065)$ than in patients with melanocyte benign congenital nevi (Fig. 8).

SFT on the shin in healthy men was significantly $(p<0.01)$ higher than in men with melanocyte benign dysplastic nevi; and in men with melanocyte benign dysplastic nevi significantly $(p<0.05)$ less or tends to lower values $(p=0.054)$ than in patients with melanocyte benign simple and melanocyte benign congenital nevi (Fig. 9).

\section{Discussion}

In the analysis of SFT between healthy and benign nevi men found (Table 1):

SFT on the anterior and posterior surfaces of the shoulder and thigh in healthy men is significantly higher than in patients with melanocyte benign simple nevi (43.0 \%, 34.2 \% and $37.7 \%$, respectively), melanocyte benign dysplastic nevi (respectively). $49.0 \%, 37.1 \%$ and $41.3 \%$ ), melanocyte benign congenital nevi (respectively $35.4 \%, 31.0 \%$ and $43.1 \%$ ) and non-melanocyte benign nevi (respectively $45.3 \%, 29.5 \%$ and $36.6 \%$ );

SFT on the forearm by $27.2 \%$, under lower angle of the shoulder blade by $10.8 \%$, on the chest by $15.0 \%$ and on the shin by $22.5 \%$ in healthy men is significantly higher than in patients with melanocyte benign dysplastic nevi;

SFT on the side in healthy men is significantly lower than in patients with benign nevi $(40.4 \%, 22.8 \%, 25.9 \%$ and $26.3 \%$, respectively);

Abdominal SFT in healthy men is significantly lower or tends to be lower than in patients with melanocyte benign prostatic $(14.6 \%)$ and non-melanocyte benign $(14.1 \%)$ nevi.

Given the significantly higher values of SFT on the side and abdomen in patients with benign nevi (most pronounced in patients with melanocyte benign simple nevi), we observe the initial manifestations of abdominal (android) type of fat deposition in the body.

In the analysis of SFT between men with benign nevi found (see table 1):

significantly lower or lower values in patients with melanocyte benign dysplastic nevi - SFT on the forearm and at the lower angle of the scapula than in patients with melanocyte benign prostatic nevi $(14.0 \%$ and $20.5 \%$, respectively) and non-melanocyte benign nevi (respectively by $15.4 \%$ and $11.6 \%$ ); SFT on the shin than in patients with melanocyte benign prostatic $(17.5 \%)$ and congenital $(17.4 \%)$ nevi; SFT on the breast than in patients with melanocyte benign congenital $(22.9 \%)$ and non-melanocyte benign $(20.1 \%)$ nevi; SFT on the side than in patients with melanocyte benign simple nevi (by $22.7 \%$ ); SFT on the posterior surface of the shoulder than in patients with melanocyte benign congenital nevi $(21.1 \%)$;

the tendency to higher values in patients with melanocyte benign simple nevi SFT on the side by $19.1 \%$ than in patients with non-melanocyte benign nevi;

the tendency to higher values in patients with nonmelanocyte benign nevi SFT on the thigh by $10.2 \%$ than in patients with melanocyte benign congenital nevi.

The multifactorial nature of human skin cancer is a longestablished scientific fact [15, 19], but anthropometric studies on the study of melanocyte skin tumors still remain few.

A review of 44 literature sources in the PubMed database revealed an association between indicators such as freckle density, eye color, hair color, family history, skin type, number of atypical and common nevi, and risk of melanoma [2].

The data of K.J. Buster and co-authors [5] suggest that the elderly, blacks, with low levels of education have a lower

Table 1. Differences in SFT between healthy and benign nevi patients, as well as between sick men.

\begin{tabular}{|l|c|c|c|c|c|}
\hline \multirow{2}{*}{ Indicators } & \multirow{2}{*}{ Healthy } & \multicolumn{5}{c|}{ Sick } \\
\cline { 3 - 6 } & & MBN & MBDN & MBCN & NMBN \\
\hline $\begin{array}{l}\text { SFT on the back of the } \\
\text { shoulder }\end{array}$ & $\Delta$ & $\nabla$ & $\nabla \nabla$ & $\nabla \Delta$ & $\nabla$ \\
\hline $\begin{array}{l}\text { SFT on the front } \\
\text { surface of the shoulder }\end{array}$ & $\Delta$ & $\nabla$ & $\nabla$ & $\nabla$ & $\nabla$ \\
\hline SFT on the forearm & $\Delta$ & $\Delta$ & $\nabla \nabla \downarrow$ & & $\uparrow$ \\
\hline $\begin{array}{l}\text { SFT at the lower angle } \\
\text { of the scapula }\end{array}$ & $\Delta$ & $\Delta$ & $\nabla \nabla \downarrow$ & & $\uparrow$ \\
\hline SFT on the chest & $\Delta$ & & $\nabla \downarrow$ & $\uparrow$ & $\uparrow$ \\
\hline SFT on the abdomen & $\nabla$ & $\Delta$ & & & $\uparrow$ \\
\hline SFT on the side & $\nabla$ & $\Delta \Delta \uparrow$ & $\Delta \nabla$ & $\Delta$ & $\Delta \downarrow$ \\
\hline SFT on the thigh & $\Delta$ & $\nabla$ & $\nabla$ & $\nabla \downarrow$ & $\nabla \uparrow$ \\
\hline SFT on the shin & $\Delta$ & $\Delta$ & $\nabla \nabla \downarrow$ & $\uparrow$ & \\
\hline
\end{tabular}

Notes: SFT - skinfold thickness; MBN - melanocyte benign common nevi; MBDN - melanocyte benign dysplastic nevi; MBCN - melanocyte benign congenital nevi; NMBN - non-melanocyte benign nevi; $\triangle$ or $\nabla$ - significant differences between healthy and sick men; $\uparrow$ or $\downarrow$ trends in differences between healthy and sick men; $\Delta$ or $\nabla$ significant differences in indicators between sick men; $\uparrow$ or $\downarrow$ tendencies of differences of indicators between sick men. 
risk of skin cancer. In general, in all groups of individuals studied, the criterion of low quality of education acted as a criterion for reducing the risk of skin cancer.

The purpose of the analysis of scientific research in the period from 1985 to 2011 revealed that obesity is a factor in the increased risk of many cancers of the human body, in particular, melanoma $(\mathrm{RR}=1.26)$ [6].

J.C. Dusingize, and co-authors [8] conducted an interesting study to find a relationship between genetically predicted constitutional characteristics of the human body and the risk of melanoma. No relationship was found with BMI, but with human growth such a relationship was found [OR 1.08, $95 \% \mathrm{Cl}: 1.02-1.13,1 \mathrm{SD}(9.27 \mathrm{~cm})$ increase in height].

Data on the association between the risk of melanoma and human growth are confirmed in another study, as well as the usefulness of using the number of nevi. In addition, it is indicated that the prevalence of melanoma is almost the same among men and women [13].

Waist circumference can be used as a marker of melanoma of the skin - as evidenced by the purpose of the analysis conducted by Korean scientists [14].

Analysis of the results of 9 publications (total number of study participants 971,795 healthy individuals and 50,561 patients with non-melanocyte skin cancer) allowed to

\section{References}

[1] Adaji, A., Gaba, P., Lohse, C. M., \& Brewer, J. D. (2016). Incidence of atypical nevi in Olmsted County: an epidemiological study. Journal of Cutaneous Pathology, 43(7), 557-563. doi: 10.1111/ cup.12709

[2] Belbasis, L., Stefanaki, I., Stratigos, A. J., \& Evangelou, E. (2016). Non-genetic risk factors for cutaneous melanoma and keratinocyte skin cancers: an umbrella review of metaanalyses. Journal of Dermatological Science, 84(3), 330339. doi: 10.1016/j.jdermsci.2016.09.003

[3] Buendia-Eisman, A., Palau-Lozaro, M. C., Arias-Santiago, S., Cabrera-Leon, A., \& Serrano-Ortega, S. (2012). Prevalence of melanocytic nevi in 8-to 10-year-old children in Southern Spain and analysis of associated factors. Journal of the European Academy of Dermatology and Venereology, 26(12), 1558-1564. doi: 10.1111/j.1468-3083.2011.04342.x

[4] Bunak, V. V. (1941). Антропометрия [Anthropometry]. М.: Наркомпрос РСФСР - M.: People's Commissariat of the RSFSR.

[5] Buster, K. J., You, Z., Fouad, M., \& Elmets, C. (2012). Skin cancer risk perceptions: a comparison across ethnicity, age, education, gender, and income. Journal of the American Academy of Dermatology, 66(5), 771-779. doi: 10.1016/ j.jaad.2011.05.021

[6] Dobbins, M., Decorby, K., \& Choi, B. C. K. (2013). The association between obesity and cancer risk: a meta-analysis of observational studies from 1985 to 2011. International Scholarly Research Notices, 2013, 680536. doi: 10.5402/ 2013/680536

[7] Donkor, C. M., Aryee-Boi, J., Osazuwa, I. R., Afflu, F. K., \& Alexis, A. F. (2021). Nevi. In Atlas of Dermatological Conditions in Populations of African Ancestry (pp. 207-217). Springer, Cham.

[8] Dusingize, J. C., Olsen, C. M., An, J., Pandeya, N., Law, M. H., Thompson, B. S. ... Whiteman, D. C. (2020). Body mass index establish nonlinear feedback between body mass index and the risk of non-melanocyte skin cancer $(R R=0.88$, $95 \%$ Cl: $0.85-0.91, \mathrm{I} 2=71.2 \%, \mathrm{p}<0.001)$. The strongest association was observed between body mass index and squamous cell carcinoma and basal cell carcinoma of the skin. Manifestations of sexual dimorphism were practically not detected, except for the reverse weak association in men [22].

A preliminary review of the literature did not reveal any publications in the available scientometric databases in the last 10 years regarding the use of anthropometric indicators to predict the occurrence of benign nevi. Thus, the results of this study are unique not only for the domestic but also for the international scientific community.

\section{Conclusion}

1. Numerous differences in SFT (higher values in healthy men, except for folds on the side and abdomen) have been found between healthy and men with benign nevi, which reflect the initial manifestations of abdominal (android) type of fat deposition in the body.

2. Differences between men with different forms of benign nevi mainly concern lower values of the majority of SFT in patients with melanocyte benign dysplastic nevi.

and height and risk of cutaneous melanoma: Mendelian randomization analyses. International Journal of Epidemiology, 49(4), 1236-1245. doi: 10.1093/ije/dyaa009

[9] Ekwueme, D. U., Guy Jr, G. P., Li, C., Rim, S. H., Parelkar, P., \& Chen, S. C. (2011). The health burden and economic costs of cutaneous melanoma mortality by race/ethnicity-United States, 2000 to 2006. Journal of the American Academy of Dermatology, 65(5), S133-e1. doi: 10.1016/j.jaad.2011.04.036

[10] Ferreira, L., Jham, B., Assi, R., Readinger, A., \& Kessler, H. P. (2015). Oral melanocytic nevi: a clinicopathologic study of 100 cases. Oral Surgery, Oral Medicine, Oral Pathology and Oral Radiology, 120(3), 358-367. doi: 10.1016/ j.0000.2015.05.008

[11] Hunt, R. D., Orlow, S. J., \& Schaffer, J. V. (2014). Genital melanocytic nevi in children: experience in a pediatric dermatology practice. Journal of the American Academy of Dermatology, 70(3), 429-434. doi: 10.1016/j.jaad.2013.10.022

[12] Kachare, S. D., Agle, S. C., Englert, Z. P., Zervos, E. E., Vohra, N. A., Wong, J. H., \& Fitzgerald, T. L. (2013). Malignant blue nevus: clinicopathologically similar to melanoma. The American Surgeon, 79(7), 651-656. doi: 10.1177/000313481307900706

[13] Kyrgidis, A. (2017). Risk factors. In Cutaneous Melanoma (pp. 11-25). Academic Press. doi: 10.1016/B978-0-12-8040003.00002-8

[14] Lee, K. R., Seo, M. H., Do Han, K., Jung, J., \& Hwang, I. C. (2018). Waist circumference and risk of 23 site-specific cancers: a population-based cohort study of Korean adults. British Journal of Cancer, 119(8), 1018-1027. doi: 10.1038/ s41416-018-0214-7

[15] Leonardi-Bee, J., Ellison, T., \& Bath-Hextall, F. (2011). Lifestyle factors of smoking, BMI and alcohol consumption on the risk of Non-Melanoma Skin cancer in adults: Systematic review. JBI Evidence Synthesis, 9(32), 1-18. doi: 10.11124/jbisrir-2011- 
409

[16] Monteagudo, B., Labandeira, J., Acevedo, A., Ramirez-Santos, A., Cabanillas, M., Corrales, A. ... Toribio, J. (2011). Prevalence and clinical features of congenital melanocytic nevi in 1,000 Spanish newborns. Actas Dermo-Sifiliograficas (English Edition), 102(2), 114-120. doi: 10.1016/S1578-2190(11)707685

[17] Potekayev, N. N., Shuginina, Y. K., Kuzmina, T. S., \& Arutyunyan, L. S. (2011). Дерматоскопия в клинической практике. Руководство для врачей [Dermatoscopy in clinical practice. A guide for doctors]. M: МДВ, 144 - M: MDV, 144.

[18] Sadoghi, B., Schmid-Zalaudek, K., Zalaudek, I., Fink-Puches, R., Niederkorn, A., Wolf, I. ... Richtig, E. (2021). Prevalence of nevi, atypical nevi, and lentigines in relation to tobacco smoking. Plos One, 16(7), e0254772. doi: 10.1371/journal.pone.0254772

[19] Si, S., Tewara, M. A., Ji, X., Wang, Y., Liu, Y., Dai, X. ... Xue, F. (2020). Body surface area, height, and body fat percentage as more sensitive risk factors of cancer and cardiovascular disease. Cancer Medicine, 9(12), 4433-4446. doi: 10.1002/ cam4.3076

[20] Tromme, I., Devleesschauwer, B., Beutels, P., Richez, P., Praet, N., Sacre, L. ... Speybroeck, N. (2014). Selective use of sequential digital dermoscopy imaging allows a cost reduction in the melanoma detection process: a Belgian study of patients with a single or a small number of atypical nevi. PLoS One, 9(10), e109339. doi: 10.1371/journal.pone.0109339

[21] Yeh, I. (2020). New and evolving concepts of melanocytic nevi and melanocytomas. Modern Pathology, 33(1), 1-14. doi: 10.1038/s41379-019-0390-x

[22] Zhou, D., Wu, J., \& Luo, G. (2016). Body mass index and risk of non-melanoma skin cancer: cumulative evidence from prospective studies. Scientific Reports, 6(1), 1-8. doi: 10.1038/ srep37691

\section{ОСОБЛИВОСТІ ТОВЩИНИ ШКІРНО-ЖИРОВИХ СКЛАДОК У ЧОЛОВІКІВ 3 ДОБРОЯКІСНИМИ НЕВУСАМИ \\ Набіль Басім Юсіф Хаддад}

Невуси, хоч і є доброякісними новоутвореннями шкіри, проте мають певну схильність до малігнізації, на що впливають різні як зовнішні, так і внутрішні фактори людини. Передбачення ризику виникнення доброякісних невусів на даному фроні $\epsilon$ актуальною темою для проведення експериментальних досліджень. Мета дослідження - встановити особливості товщини шкірно-жирових складок (ТШЖС) у чоловіків першого зрілого віку, хворих на доброякісні невуси. Проведено визначення ТШжС за схемою Бунака чоловікам (віком 22-35 років), хворим на меланоцітарні доброякісні прості невуси (n=34), меланоцітарні доброякісні диспластичні невуси (n=27), меланоцитарні доброякісні вроджені невуси (n=14) та немеланоцитарні доброякісні невуси (n=17). Контрольна група - ТШжС 82 практично здорових чоловіків аналогічної вікової групи відібрана з банку даних науково-дослідного центру Вінницького національного медичного університету імені М.І. Пирогова. Статистичну обробку результатів проведено в ліцензійному пакеті "Statistica 5.5" з використанням непараметричних методів оцінки. Встановлено, що у практично здорових чоловіків більші, ніж у хворих - ТШЖС на передній та задній поверхнях плеча і на стегні (в усіх групах хворих); ТШЖС на передпліччі, під нижнім кутом лопатки, на грудях і на гомілці (лише у хворих на меланоцитарні доброякісні диспластичні невуси). Також у здорових чоловіків встановлені менші, ніж у хворих - ТШжС на боку (в усіх групах хворих); ТШЖС на животі (у хворих на меланоцитарні доброякісні прості та немеланоцитарні доброякісні невуси). При порівнянні ТШЖС між хворими на доброякісні невуси чоловіками, в більшості випадків, встановлені менші значення ТШжС у хворих на меланоцитарні доброякісні диспластичні невуси. Отримані результати вказують на початкові прояви абдомінального (андроїдного) типу відкладення жиру в організмі у хворих на доброякісні невуси (найбільш виражені у хворих на меланоцитарні доброякісні прості невуси).

Ключові слова: доброякісні невуси, товщина шкірно-жирових складок, чоловіки. 